\title{
Új normák a közigazgatásban? Elektronikus kapcsolattartástól az elektronikus közigazgatásig
}

\author{
New standards in public administration? From the electronic \\ communication to the electronic public administration
}

\section{SZALÓKI I. ${ }^{1}$}

\author{
Debreceni Egyetem Marton Géza Állam- és Jogtudományi Doktori Iskola, Tanszék: Közigazgatási Jogi \\ Tanszék, drszaloki.istvan@gmail.com
}

Absztrakt

A PHD kutatásom célja, hogy egy átfogó képet adjak a magyar elektronikus közigazgatás jogi szabályozásáról, helyzetéről megoldásairól a nemzetközi jogi szabályozás „,feltárásával” a 21. században. Különös figyelmet kívánok fordítani az e-közigazgatás által generált változásokra úgy, mint például az eljárásjogi szakban lévő szereplök szerepének, jogainak és kötelezettségeinek változásaira, átalakulására. Kérdésként merül fel, hogy amikor elektronikus eljárásról beszélünk, akkor csak egy kapcsolattartási módot, eljárási jellemzöt emelünk ki, vagy egy külön eljárási típusról értekezhetünk. Jelen tanulmány keretében szeretném megismertetni kutatásom kezdetén feltárt hipotéziseimet és vizsgálati szempontokat, és az elektronikus közigazgatás fontosabb fogalmait, melyek jelentős mértékben meghatározzák kutatásom előrehaladásának menetét, irányait. Jelen tanulmányban elsősorban hipotéziseimet teszem fel, vizsgálati szempontokat fogalmazok meg, továbbá a magyar jogszabályi környezetben az elektronikus közigazgatás alapvető fogalmait vizsgálom úgy, mint alapelvek, az elektronikus közigazgatás szereplői és technikai fogalmak.

Kulcsszavak: elektronikus közigazgatás, Eüsztv., e-ügyintézés, SZEÜSZ, közigazgatási eljárás

JEL Kódok: H83, K19, K23

Abstract

The aim of my PHD research is to give a comprehensive picture of about the Hungarian electronic public administration's legal regulation and its solutions by "exploring" the international legal regulation in the century of 21. I would like to pay particular attention to the changes generated by eGovernment, such as for example: the changes and development in the persons' role, rights and obligations. The question arises that when we speak of electronic procedure, we only emphasize one type of communication, a procedural feature, or a separate type of procedure. In the context of this essay, I would like to introduce my hypotheses and research aspects that have been discovered at the beginning of my research, and the more important concepts of the electronic public administration, which significantly determine the course and directions of my research progress. In this research first of all, I prepare my hipotesis, draft my researching aspects, furthermore at the hungarian law environment I analyse the electronic public administration's concepts, such as basic principles, the electronic public administration's persons and technical concepts.

1ORCID azonosító: https://orcid.org/0000-0003-2872-3895, Témavezető: Répásiné Dr. Veszprémi Bernadett egyetemi adjunktus

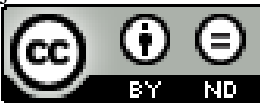


Keywords: electronic public administration, Eüsztv., e-administration, SZEÜSZ, public administration procedure

JEL Codes: H83, K19, K23

\section{Bevezetés}

Doktoranduszi kutatásom témájául az elektronikus közigazgatás jogelméleti és joggyakorlati jelenének és jövőjének bemutatására vállalkoztam a XXI. században, lokálisan behatárolva elsősorban a magyar közigazgatásban. Szakágazati szinten kiemelt figyelmet szánok az elektronikus adó- és vámigazgatási eljárások témájára. Jelen tanulmányban elsősorban a kutatásom jogdogmatikai alapjaival (fontosabb fogalom meghatározásokkal) kívánok foglalkozni kezdeti hipotéziseimen, vizsgálati szempontjaimon keresztül, továbbá meg kívánom határozni az elektronikus közigazgatás alapvető fogalmait az Eüsztv. rendelkezéseinek elemzésével.

Jelen esszének nem célja, hogy választ adjon a kezdeti kutatás feltett, vagy még fel nem tett valamennyi kérdésére, mert ez a kutatásom jelenlegi szakaszában lehetetlen feladat. Az esszé célja, hogy megfogalmazza azokat a kezdeti kérdéseket, hipotéziseket, amelyek a teljes kutatásomat átívelik, változnak, formálódnak, beigazolódnak, vagy megcáfolódnak. Összefoglalva az esszé célja kérdések, hipotézisek feltevése, vizsgálati szempontok meghatározása és az elektronikus közigazgatás szempontjából releváns alapelvek, fogalmak, technikai fogalmak vizsgálata, vizsgálatának megalapozása elsősorban jogi, másodsorban technikai, elsősorban jogelméleti, másodsorban joggyakorlati szempontból. Fontos egyfajta rövid jogtörténeti, pontosabban jogintézmény-történeti áttekintéssel kezdenünk. Mivel a közigazgatási eljárásjog a maga nemében egy páratlan, Hans Kelsen szemszögéből tekintve tiszta jogtudományi részterület megfosztva minden felesleges társadalomtudományi jellemzőtől és néha magától a szabályozás alanyától is (belső technikai, szervezetmüködéssel kapcsolatos utasítások), mégis megfogyatkozott az elmúlt évtizedekben „követőinek” száma, ezért fontos, hogy egy jogintézményi alappal szolgáljak azon személyek számára is, akik nem töltik mindennapjaikat a közigazgatás „,berkeit” kutatva.

A Ket 28/A. §-a² értelmében a jogszabály elsősorban egy kapcsolattartási módról, míg a Ket. 160. §-a ${ }^{3}$ a tényleges elektronikus ügyintézés, azaz elektronikus eljárás biztosításáról egyfajta lehetőségként rendelkezett, amennyiben ez az adott cselekmény vonatkozásában értelmezhető. Kezdetben - az Eüsztv. ${ }^{4}$ hatálybalépése előtt - a hatóságok (elektronikus ügyintézést biztositó szervek) által ügyfelek számára garantált elektronikus szolgáltatások köre szük volt, és nem volt biztosítva az a megfelelő jogszabályi

\footnotetext{
${ }^{2}$ A közigazgatási hatósági eljárás és szolgáltatás általános szabályairól szóló 2004. évi CXL. törvény (a továbbiakban: Ket.) 28/A. $§$ (1) „A hatóság írásban, az elektronikus ügyintézés és a bizalmi szolgáltatások általános szabályairól szóló törvényben meghatározott elektronikus úton (a továbbiakban együtt: irásban), vagy személyesen, irásbelinek nem minösülö elektronikus úton (a továbbiakban együtt: szóban) tart kapcsolatot az ügyféllel és az eljárásban résztvevőkkel."

${ }^{3}$ Ket. 160. §,Az eljárás minden szereplöje a törvényben meghatározottak szerint jogosult, illetve köteles az eljárási cselekményeit - igy különösen nyilatkozatát, döntését - elektronikusan teljesiteni, ha az az adott eljárási cselekmény vonatkozásában értelmezhetö."

${ }^{4} \mathrm{Az}$ elektronikus ügyintézés és a bizalmi szolgáltatások általános szabályairól szóló 2015. évi CCXXII. törvény (a továbbiakban: Eüsztv.)
} 
háttér, amely alapján a hatóságok el tudták volna kezdeni eljárásaik elektronikus színtérre történő átültetését. Számtalan olyan szakágazati, az elektronikus ügyintézés szempontjából szakmai és technikai jogszabályi rendelkezés hiányzott, amely alapján az elektronikus ügyintézés útja „valós” alternatívát jelenthetett volna a hatóságok számára.

Tényleges jogi szabályozást a 2016. január 1-jétől hatályba lépett Eüsztv. biztosított mind a hatóságok, mind az ügyfelek számára. Az Eüsztv. megerősítette a Ket. által felállított jogalkotói hozzáállást az elektronikus ügyintézés alkalmazása/alkalmazhatósága vonatkozásában ugyanis - véleményem szerint - az Eüsztv. alkalmazása során a jogalkotó már alapvető feltételnek tekintette az elektronikus ügyintézés/eljárás biztosítását a hatóságok (későbbi hivatkozások során: elektronikus ügyintézés biztosítására kötelezett állami szervek) részéről, míg az ügyfelek részéről ezek igénybevételét. (a. hipotézis) Az Eüsztv. az elektronikus ügyintézés során kizárólag egy részelemnek tekinti az elektronikus kapcsolattartást, ám ez elöfeltétele a teljes eljárás elektronikus lefolytathatóságának. Az elektronikus közigazgatás többletkötelezettséget vár el mind a hatóságoktól, mind pedig az ügyfelektöl, tehát:

- kezdetben adminisztratív tehernövekedéssel jár (pl.: ügyfélkapu regisztráció személyes ügyintézés útján, kötelező elektronikus tárhely használat), valamint az elektronikus eljárások és szolgáltatások igénybevétele is többlet terhet, vagy

- bizonyos szolgáltatások kötelezõ igénybevételét írja elö, mint az ügyfelek/hatóságok számára (pl.: KAÜ azonositási szolgáltatás alkalmazása, cégkapu nyitás kötelezettsége a gazdálkodó szervezetek számára).

További példaként megemlíthető, hogy az Eüsztv. például az együttmüködő szervek között kapcsolattartás vonatkozásában kötelezettségként rendelkezik az elektronikus kapcsolattartásról, a jogszabály egyes ügyfelek szempontjából kötelezettségként rendelkezik az elektronikus ügyintézésről (nem lehetőségként). Ezt a hozzáállást „ültette” át a jogalkotó egyre több ágazati jogszabályba is, pl.: építésügy, adóigazgatás, vámigazgatás... stb.

\section{Elektronikus ügyintézés kapcsolatos anticipációk}

Az elektronikus közigazgatás, vagy e-ügyintézés kezdeti másodlagos szerepéhez képest 2016. január 01-jétől - megerösitve a Ket.-ben ,gyökerezö” elektronikus közigazgatás alapjait - folyamatosan egy erősödő és egyenragú opcióként jelentkezik az elektronikus szolgáltatások terjedésével, és a klasszikus „papír alapú” közigazgatási és egyéb eljárások ,,igazi” konkurenseként jelentkezik. Természetesen az eügyintézési lehetőség bizonyos kötöttségekkel, és ezen kötöttségekért/kötelezettségekért járó előnyökkel is jár egyszerre mind az ügyfelek, mind a hatóságok számára. Ha összegezni szeretnénk és le kívánjuk egyszerüsíteni valamennyi kutatási szempontomat (Isd. részletesebben III. fejezet) az elektronikus ügyintézés vonatkozásában, hogy az valamennyi laikus számára érhetővé váljon, akkor a kutatásom alapvető kérdése/vizsgálati szempontja: 
„Milyen kötöttségeket követel meg az elektronikus ügyintézés alternatívája az eljárás résztvevöitöl, és ezen kötelezettségek teljesitése kellö „hasznot” biztosit-e az eljárás valamennyi résztvevöje számára, szemben a klasszikus (,papíros”) közigazgatási eljárásokkal?”

Ezen alapvető kérdés igazolása érdekében kutatásom kezdetén az alábbi alapvető hipotéziseket kívánom felállítani, melyek igazolására, vagy megcáfolásra (későbbi tanulmányaim során, nem jelen alapozó tanulmányban) törekszem:

- (b. hipotézis) Az elektronikus út egyik hátránya, hogy a közvetett kommunikáció eredményeként az ügyfél személyének azonosítása ${ }^{5}\left(p 1 .: \mathrm{KAÜ}^{67}\right.$ ):

○ (b/1.) az elektronikus eljárások effektíve gyors lefolyása és közvetettsége miatt fontos alappillérévé vált az elektronikus közigazgatásnak és

○ (b/2.) új közigazgatási szolgáltatások alkalmazását tették kötelezővé az ügyfelek számára az eljárási jogosultságuk és eljárásbeli pozícióik tisztázása érdekében,

○ (b/3) továbbá a szabályozás keretjellegére tekintettel olyan jogi garanciák értékelődtek át, mint például a személyes adatok védelme, amelyet újra kellett értelmezni, mind a jogalkotónak, mind a jogalkalmazónak, ezért az eljárások kezdetben akadoztak (pl.: RNY nyilatkozat, Cégkapu jogosultság kezelés, elektronikus tárhely regisztráció...stb.).

Fontos megjegyezni, hogy a $\boldsymbol{K} \boldsymbol{A} \ddot{U}^{8}$-s azonositás kötelezettségét, valamennyi elektronikus eljárásban résztvevő ügyféltől megkövetelik az együttmüködő szervek, mert függetlenül attól, hogy a konkrét ügyben az ügyfél nem természetes személy például: Kft-ként müködik, de a jogi személy képviseletében, vagy törvényes képviselöjeként „,végsösoron” minden esetben egy önálló, vagy együttes képviselet esetén legalább kettő természetes személy jár el. Ennek a természetes személynek az elektronikus ügyintézés/szolgáltatások igénybevétele elött be kell azonosítani magát és ezt a személyt az Összerendelési Nyilvántartásnak is viszont kell azonosítania. Összegezve - a fentebb leírtakat - a KAÜs azonosítás technikai és szakmai előfeltétele a központi elektronikus ügyintézési szolgáltatások (KEÜSZ) igénybevételének.

- (c. hipotézis) Általánosan kijelenthető, hogy az elektronikus eljárások terjedésével párhuzamosan:

○ (c/1.) az eljárási jogok és kötelezettségek átalakultak,

○ (c/2.) klasszikus jogintézmények, eljárási elemek nyernek részben, vagy teljesen új értelmet úgy, mint pl.: az eljárási határidök, a kézbesitettség tényének visszaigazolása, a hivatalos küldemény kiküldésének elsödleges útja, a kézbesitési vélelem fogalma... stb.

\footnotetext{
${ }^{5}$ Bővebben: Veszprémi B. (2019): A stratégiai-alkotástól az e-hitelesitésig vezetö út. Kitekintés a magyar e-közigazgatás fontosabb témaköreire, Debreceni Egyetemi Kiadó, Debrecen, 2019., pp. 222-240.

${ }^{6}$ Bővebben a KAÜ-röl: Központi Azonositási Ügynök. https://ugyintezes.magyarorszag.hu/szolgaltatasok/kau.html, 2019.12.30.

${ }^{7}$ e-SZIG bevezetésével kapcsolatban: Architecture for a European interoperable eID system within a smart card infrastructure, CEN Workshop Agreement, CWA 15264-1, 2005. https://joinup.ec.europa.eu/solution/architecture-european-interoperable-eid-system-withinsmart-card-infrastructure, 2020.01.01.

${ }^{8}$ Az elektronikus ügyintézés részletszabályairól szóló 451/2016. Korm. rendelet (a továbbiakban: E-ügyintézési rendelet) 69-71. §-ai
} 
○ (c/3.) szinte a közigazgatási eljárás valamennyi eleme átalakult/átalakulóban van, néhol egyszerüsödött, informatikailag egyértelművé, de máshol szakmailag bonyolultabbá, kissé „homályossá” vált.

A c/3. pontban foglaltak szempontjából kiemelendő az interoperabilitás ${ }^{9}$, mint az elektronikus szolgáltatások, rendszerek és nyilvántartások között megvalósult, vagy megvalósuló informatikai és szakmai követelmény, amely elsősorban informatikai követelményként jelentkezik, és az egyes hivatalok közötti „kommunikáció”, informatikai átjárhatóságot hivatott megteremteni az elektronikus eljárások/szolgáltatások és nem utolsó sorban szakmai kritériumok kiterjeszthetősége érdekében.

- (d. hipotézis) Az elektronikus közigazgatási fejlődés egyik sajátos eredménye, hogy az eközigazgatási eljárásokban és így a klasszikus közigazgatási eljárásokban differenciálódott az ügyfél fogalma, melynek egyik eredménye, hogy a nem természetes személy ügyfelek - többsége vonatkozásában általános követelménnyé vált például: az elektronikus tárhely alkalmazása (Cégkapu, Hivatali tárhely), az e-Papír útján történö kommunikáció... stb.. Az elektronikus kapcsolattartási mód kezdi „kinőni” önmagát és a jelenlegi szabályozási környezet olyan irányba fejlődik tovább, hogy az elektronikus eljárások önálló és speciális eljárási jogi kódexet teremtenek maguknak. Ennek ékes példájaként említhető az Eüsztv., amely kvázi általános „elektronikus” eljárási kódexként próbál ,funkcionálni”.

- (e. hipotézis) Az elektronikus szolgáltatások terjedése átformálja a klasszikus értelemben vett hatósági kötelezettségeket, differenciálja az ügyfelekkel való hatósági kommunikációt és „bánásmódot”, valamint új és ingyenes közszolgáltatások bevezetését teszi kötelezővé a hatóságok számára az ügyféli jogok és kötelezettségek elektronikus úton történő gyakorlásának biztosítása érdekében:

○ (e/1.) a hatóságok az elektronikus közigazgatás/eljárások terjedésével fokozatosan „eszolgáltatókká" válnak,

○ (e/2.) a bürokrácia csökkentése érdekében egyre jobban terjednek az olyan szolgáltatások, amelyek az ügyféli kötelezettségek (például: bejelentkezési/bejelentési kötelezettség) egyszeri teljesítését teszik kötelezővé, ezt követően a törvény - a jogalkotói szándékkal egyezően és az ügyféli terhek csökkentése érdekében - kvázi egyes hatóság(ok) kötelezettségévé teszi az ügyfél által bejelentett adatok továbbítását. Itt említhetjük példaként a helyi adókról szóló 1990. évi C. törvény (Htv.) 42/E. §-a szerinti adatszolgáltatási kötelezettséget, amely az állami adó- és vámhatóság kötelezettségévé teszi a NAV-hoz közvetlen, vagy közvetett módon érkező - a jogszabályban meghatározott adatoknak az adózók székhelye szerinti - és 2020. január 01-jétöl a NAV-hoz közvetlenül bejelentett Htv. alapján telephelye szerinti - önkormányzatok részére történő továbbítását.

${ }^{9}$ Bővebben: Veszprémi B. (2019): Az interoperabilitás kérdésének boncolgatása a közigazgatásban, Pro Publico Bono, Magyar Közigazgatás, 2018/2., pp. 174-184. 
○ (e/3.) egyszerüsödnek a törvényi kötelezettségek például: interaktív elektronikus felületen számos szolgáltatás elérhető, vagy kötelezettség teljesíthető ( $e B E V, S Z \ddot{U} F$, webes Ügysegéd).

○ (e/4.) egyre könnyebb felvenni a hatóságokkal a kapcsolatot, akár okos telefonon is lehet ügyet intézni.

- (f. hipotézis) Az elektronikus ügyintézés - meglátásom szerint - képes teljesíteni azon elsősorban ügyféli jogokat garantáló közigazgatási alapelveket, amelyek biztosítják: az egyszerü, gyors, szakszerü és átlátható közigazgatási eljárások - hatósági tevékenység - megvalósulását.

\section{Vizsgálati szempontok}

Jelen részben összegezni kívánom azon vizsgálati szempontokat, amelyek szükségesek a II. fejezetben foglalt hipotézisek igazolásához, s amelyeket kutatásom során érvényesíteni kívánok, az alábbiak szerint:

1. Az elektronikus közigazgatás által megalapozott jogi és - érintőlegesen - technikai környezetben teljes körüen érvényesülnek-e az általános jogelvek, eljárásjogi elvek, közigazgatási eljárási jogi alapelvek, adórendtartási és adóigazgatási elvek, vagy esetlegesen ezek a közigazgatási, vagy speciálisan adóigazgatási eljárás során megfogalmazott (alap)elvek „átformálódtak”, vagy „továbbfejlődtek”?

2. Milyen változásokat eredményezett az elektronikus út a klasszikus eljáráshoz képest pl.:

a. Változott-e az ,alapértelmezett” kapcsolattartási forma a közigazgatási/adóigazgatási eljárásokban,

b. Változott-e az ügyfél/adózó fogalma, a képviselők szerepe, jogaikra és kötelezettségeikre milyen kihatással volt az elektronikus út,

c. Azonosíthatóak-e a közigazgatási/adóigazgatási eljárások jelenlegi szabályozási környezetében olyan szempontok, amelyek alapján az ügyfelek között jogosultságokat, kötelezettségeket tekintve csoportokat alkothatunk?

d. Változott-e a hatóság/adóhatóság fogalma, léptek-e be új szereplők (egyéb eljárási résztvevők) a közigazgatási/adóigazgatási eljárásba,

e. Változtak-e az adatkezelési szabályok, hogyan érvényesül a személyes adatok védelme, változott-e a tájékoztatási kötelezettség szabályozása,

f. Változtak-e a kézbesítés szabályai és a kézbesítési fikció fogalma, „beállásának” módja az elektronikus út következtében...stb.

3. Az EU milyen célokat fogalmazott meg az elektronikus közigazgatás „,hajnalán”, ezek a célokat a magyar jogalkotás milyen módon ültette át a jogszabályokba, vannak-e még hiányosságai a magyar jogszabályai környezetnek, merre tart a jövő e-közigazgatása? Milyen elvárásokat fogalmazott meg az OECD a tagállamok vonatkozásában, mely OECD riportok vannak kihatással az elektronikus 
közigazgatás/adóigazgatás fejlödésének irányára? Megtalálhatóak-e olyan célkitüzések a nemzetközi/közösségi jogi környezetben, amelyeket Magyarországnak figyelembe kellett, figyelembe kell, vagy javasolt figyelembe venni az elektronikus közigazgatás hazai környezetének szabályozása során?

4. Szükségesnek tartom, hogy feltárjam ,az adatkezelés és védelem az adóigazgatási eljárásban” érvényesülő elvi és gyakorlati kihívásait úgy, mint:

a. Az adózókról jelenleg milyen közhiteles nyilvántartások léteznek, amelyeket az állami adó- és vámhatóság jelenlegi rendszerében felhasznál az adóigazgatási eljárások során?

b. Az állami adó- és vámhatóság adóalany-nyilvántartási rendszere milyen elsődleges adatokat tartalmaz, amely szempontjából közhitelesnek minősül és milyen más szervek adataira építi nyilvántartását, amelyek befolyásolják nyilvántartását?

c. Milyen adatok vannak kihatással az elektronikus adó- és vámigazgatási eljárásokra?

d. A klasszikus adó- és vámigazgatás, valamint az elektronikus adó- és vámigazgatás eltérő eljárásokat alakított ki, vagy az elektronikus út csak egy kapcsolattartási típust határoz meg az eljárás során, de nem képez külön-eljárást?

Az EU elektronikus közigazgatással kapcsolatos trendeket követve meg kívánom vizsgálni, hogy a magyar elektronikus közigazgatás is megvalósítja-e azokat az EU által elöírt célokat, amelyeknek az EU fejlett és fejlődő országainak - egyaránt - meg kell valósítaniuk. Példaként említhető Tózsa István ${ }^{10}$ által is vizsgált e-közigazgatással kapcsolatos elvárások (Tózsa, 2012):

1. „az ügyfélbarát közigazgatás,

2. a befogadó közigazgatás,

3. az elektronikus dokumentumkezelés,

4. interoperabilitás,

5. tartalommenedzsment."

\section{Az elektronikus ügyintézés fontosabb alapfogalmai az Eüsztv. nyomán:}

A törvényi szabályozás mögötti jogalkotói cél a hatóságok és ügyfél, valamint a hatóságok viszonylatában

$>$ az elektronikus ügyintézés széles körü elterjedése,

$>$ az eljárások gyorsítása és az adminisztratív terhek csökkentése,

$>$ a magánjogi jogviszonyok, továbbá az állam és polgár közötti jogviszonyok szélesebb körü elektronizálása,

\footnotetext{
${ }^{10}$ Tózsa I. (2012): Az elektronikus közigazgatás helyzete, Új Magyar Közigazgatás, 2012/5., pp. 2-12.
} 
$>$ az elektronikus ügyintézést biztosító szervek együttmüködésének biztosítása, valamint

> a lakosság számára a korszerübb és hatékonyabb közszolgáltatások nyújtása a lakosság számára a korszerübb és hatékonyabb közszolgáltatások nyújtása.

A törvényhozó további célja volt az Eüsztv. megalkotásával, a belső piacon történő elektronikus tranzakciókhoz kapcsolódó elektronikus azonositásról és bizalmi szolgáltatásokról, valamint az 1999/93/EK irányelv hatályon kivül helyezéséről tárgyú, az Európai Parlament és a Tanács 910/2014/EU rendeletben (a továbbiakban: $\boldsymbol{e I D A S}$ rendelet) foglalt rendelkezések tagállami végrehajtását elősegítő jogszabályi környezet megteremtése, az eIDAS rendeletnek való megfelelés.

Az Eüsztv. kódexszerüen kívánja rendezni az elektronikus ügyintézés nélkülözhetetlen alapvető fogalmait. Melyek közül ki kívánom emelni azokat, melyek ismeretében kellő megalapozással rendelkezhetünk ahhoz, hogy az elektronikus közigazgatás „berkeiben” kutakodhassunk.

\subsection{Elektronikus ügyintézés alapelvei}

- Magyarországon minden ügyfélnek joga van ahhoz, hogy az elektronikus ügyintézést biztosító szerv elött ügyeit elektronikusan intézze ${ }^{11}$. Az ügyfél ezzel kapcsolatos jogait az Eüsztv. 8. §-a ${ }^{12}$ részletesen kifejti.

- a beadvány elektronikus benyújtása során alkalmazott szolgáltatások, elektronikus kapcsolattartási módok és technikai eszközök igénybevételéről vélelmezni kell, hogy azokat jogszerüen veszik igénybe ${ }^{13}$.

- az Eüsztv. 1. $\S 17$. pontja szerint az elektronikus ügyintézést vállaló szerv az egyszerübb és költséghatékonyabb eljárás érdekében a jogszabályban, vagy ÁSZF-ben meghatározott ügyintézési határidőknél rövidebb határidőt is vállalhat, amennyiben az nem hat ki a normál (klasszikus) ügymenetben lefolytatott eljárások ügyintézési határidejére ${ }^{14}$.

- az elektronikus ügyintézést szabályzó jogszabály nem tartalmazhat olyan követelményt, amely valamely meghatározott müszaki megvalósítás, vagy megoldás kötelező alkalmazását írja elő az ügyfél számára kivéve:

\footnotetext{
${ }^{11}$ Eüsztv. 3. $§(1)$ bekezdése

${ }^{12}$ Eüsztv. 8. §-a szerint: ,,(1) Az ügyfél-törvény, eredeti jogalkotói hatáskörben megalkotott kormányrendelet eltérő rendelkezése hiányában - jogosult az elektronikus ügyintézést biztositó szerv elött az ügyei intézése során ügyintézési cselekményeit elektronikus úton végezni, nyilatkozatait elektronikus úton megtenni.

(2) Nincs helye elektronikus ügyintézésnek azon eljárási cselekmények esetében, ahol törvény, eredeti jogalkotói hatáskörben megalkotott kormányrendelet az ügyfél személyes megjelenését vagy meghatározott okiratok másként nem pótolható benyújtását kötelezövé teszi.

(3) Törvény, eredeti jogalkotói hatáskörben megalkotott kormányrendelet az elektronikus ügyintézés lehetöségét csak annyiban korlátozhatja, ha az eljárás során az ügyfél személyes jelenléte vagy valamely okiratok másként nem pótolható benyújtása elengedhetetlen.

(4) Nincs helye elektronikus ügyintézésnek olyan eljárási cselekmény esetében, ahol ez nem értelmezhetö.

(5) Nincs helye elektronikus ügyintézésnek olyan eljárás vagy eljárási cselekmény esetében, ahol ezt nemzetközi szerzödés vagy az Európai Unió általános hatályú, közvetlenül alkalmazandó kötelezö jogi aktusa kizárja.

(6) Nincs helye elektronikus ügyintézésnek olyan irat, okirat vagy más beadvány esetében, amely minösitett adatot tartalmaz."

${ }^{13}$ Eüsztv. 3. $\$(3)$ bekezdése

${ }^{14}$ Eüsztv. 4. § (1) bekezdése
} 
○ a kormányzati célú hálózatokról szóló kormányrendeletben meghatározott kormányzati célú hírközlési szolgáltatást, valamint

○ az állam által ingyenesen biztosított infokommunikációs szolgáltatások igénybevételét ${ }^{15}$.

- az Eüsztv. a Ket. és az Ákr. mintájára szintén megköveteli azokat a klasszikus közigazgatási eljárásjogi alapelveket, hogy az elektronikus ügyintézés során az elektronikus ügyintézést biztosító szerv (ebben a kontextusban értsd: hatóság) és az ügyfél jogaik gyakorlása és kötelezettségeik teljesítése során ${ }^{16}$ :

○ a jóhiszemüség és tisztesség, valamint

○ a kölcsönös együttmúködés követelményének megfelelően kötelesek egymással, az eljárás egyéb résztvevőivel és az eljárás joghatására tekintettel esetlegesen harmadik személyekkel szemben eljárni, jogaikat gyakorolni, kötelezettségeiket teljesíteni.

- az elektronikus ügyintézést biztosító szerv az elektronikus ügyintézést támogató és jogszabályi feltételeket biztosító rendszerfolyamatait az ügyféli érdekek (jogok) figyelembevételével köteles kialakítani $^{17}$.

- az elektronikus ügyintézést biztosító szerv az e-ügyintézés során és a bevont társszervekkel való kapcsolattartást biztosító „background” folyamatait, belső működését teljes körüen köteles elektronizálni és ehhez szükséges elektronikus rendszereket biztosítani ${ }^{18}$.

- az elektronikus ügyintézés fontos alappillére, hogy „biztositani kell a közérdekü, illetve közérdekböl nyilvános adatok megismerhetöségét és a személyes, a minősített és a nem nyilvános adatok védelmét." 19

\subsection{Az elektronikus ügyintézés (eljárás) „szereplöi”}

Elektronikus ügyintézést biztositó szerv ${ }^{20}$, nem más, mint a hatóságok fogalom meghatározása az elektronikus ügyintézés szempontjából, melynek értelmében például:

- államigazgatási szervek,

- helyi önkormányzatok,

- közigazgatási hatósági jogkört gyakorló egyéb jogalanyok,

- Országos Bírósági Hivatal és bíróságok,

- az ombudsman,

- az ügyészség,

- a közüzemi szolgáltatók, és végül, de nem utolsó sorban

- a jogszabályok szerint elektronikus ügyintézés biztosítására kötelezettek a közfeladatot ellátó szervezetek... stb.

\footnotetext{
${ }^{15}$ Eüsztv. 5. \$

${ }^{16}$ Eüsztv. 6. $\S(1)$ bekezdése

${ }^{17}$ Eüsztv. 6. § (2) bekezdése

${ }^{18}$ Eüsztv. 6. § (3) bekezdése

${ }^{19}$ Eüsztv. 7. $\$$-a

${ }^{20}$ Eüsztv. 1. $\S 17$. pontja
} 
Elektronikus ügyintézés biztosítására kötelezett állami szerv ${ }^{21}$, a jogalkotó az elektronikus ügyintézést biztosító szervek fogalom-meghatározását alapul véve tételesen meghatározza azon szervezeteket és személyeket, amelyek nem csak jogosultak, de kötelezettek is az elektronikus ügyintézés biztosítására. Fontosnak tartom kiemelni, hogy az Eüsztv. 17. pont 1) alpontja szerint lehetősége van a-k) alpontok alá nem tartozó egyéb szervezeteknek az elektronikus ügyintézés biztosítására, amennyiben ezt az Elektronikus Ügyintézés Felügyeletének ${ }^{22}$, ám ha ezen szervezet a jogszabályok szerint állami, vagy önkormányzati szervnek minősül, akkor ez a szervezet is elektronikus ügyintézésre biztosítására lesz kötelezett. (Ilyen szempontból kijelenthetjük, hogy az önként vállalt jogosultság ezen egyéb szervezetek szempontjából az Eüsztv. által kötelezettséggé válik, amennyiben a jogszabályban foglalt kritériumok teljesülnek.)

Az elektronikus ügyintézés hatósági oldala szempontjából kiemelt jelentőségú az Eüsztv. által nem a fogalom-meghatározások között, hanem a későbbi szabályozás során bevezetett gyüjtőfogalom, azaz az együttmüködó szervek. Az Eüsztv. 51. §-a szerint együttmüködő szerveknek minősülnek:

- az elektronikus ügyintézést biztosító szervek és

- a Kormány által kijelölt közfeladatot ellátó szervek.

A jogalkotó által bevezetett gyüjtőfogalom - az Eüsztv. így is bonyolult fogalomhasználatához és rendelkezéseihez képest - nem volt cél nélkül, mert mint a fogalom meghatározás is ,árulkodik” róla a szervek közötti kapcsolattartás, kommunikáció módját/csatornáját, információ átadás, lényegében az együttmüködés alapelveit hivatott kezelni. (Lsd. részletesebben az Eüsztv. X. fejezete)

Az elektronikus ügyintézésre kötelezett ügyfelek szempontjából kiemelt jelentőséggel bír a gazdálkodó szervezetek $^{2324}$ fogalom meghatározása. Amely szerint gazdálkodó szervezetnek minősül:

○ a Pp. szerint meghatározott ${ }^{25}$,

○ belföldi székhellyel rendelkező gazdálkodó szervezet,

○ azzal az eltéréssel, hogy az Eüsztv. alkalmazásában nem minősül gazdálkodó szervezetnek az adószámmal nem rendelkező:

\footnotetext{
${ }^{21}$ Eüsztv. 1. § 17a. pontja

${ }^{22}$ Eüsztv. 1. § 18. pontja alapján a Kormány által kijelölt szervezet, amely a gyakorlatban lényegében a Belügyminisztérium SZMSZ-ében kijelölt szervezeti egysége.

${ }^{23}$ Eüsztv. 1. $§ 23$. pontja

${ }^{24}$ A jogalkalmazás szempontjából nem teljesen világos fogalom-meghatározás a gazdálkodó szervezetek vonatkozásában:

Az Eüsztv. fogalom-meghatározását követve a Pp. szerint gazdálkodó szervezetnek minősülnek a köztestületek, de az Eüsztv. 1. § 17. pontja ezen szervezeteket első sorban elektronikus ügyintézést biztosító szerveknek tekinti - a hegyközségek kivételével -. Ezt azért fontos kiemelni, mivel az elektronikus ügyintézés szabályainak alkalmazása során a köztestületeket, vagy a közfeladatot ellátó például: gazdasági társaságokat nem lehet egyszerre együttmüködő szervként és ügyfélként kezelni. Viszont ezen kivételes elbánásra vonatkozó rendelkezés a gazdálkodó szervezet fogalom-meghatározásából hiányzik, így az elektronikus ügyintézést biztosító hatóságoknak konkrét közigazgatási ügyekben kellett az Eüsztv. által nem szabályozott joghézagokat a jogszabály rendszeréhez és logikájához igazítaniuk.

${ }^{25}$ A Pp. 7. § 6. pontja szerint , gazdálkodó szervezet: a gazdasági társaság, az európai részvénytársaság, az egyesülés, az európai gazdasági egyesülés, az európai területi társulás, a szövetkezet, a lakásszövetkezet, az európai szövetkezet, a vizgazdálkodási társulat, az erdöbirtokossági társulat, a külföldi székhelyü vállalat magyarországi fióktelepe, az állami vállalat, az egyéb állami gazdálkodó szerv, az egyes jogi személyek vállalata, a közös vállalat, a végrehajtói iroda, a közjegyzöi iroda, az ügyvédi iroda, a szabadalmi ügyvivöi iroda, az önkéntes kölcsönös biztositó pénztár, a magánnyugdijpénztár, az egyéni cég, továbbá az egyéni vállalkozó, emellett gazdálkodó tevékenységével összefüggö polgári jogi kapcsolataiban az állam, a helyi önkormányzat, a költségvetési szerv, jogszabály alapján a költségvetési szervek gazdálkodására vonatkozó szabályokat alkalmazó egyéb jogi személy, az egyesület, a köztestület, valamint az alapítvány. "
} 
- egyesület,

- alapítvány.

Az Eüsztv. egyik jelentős hiányossága/hibája - véleményem szerint - a szabályozás nagyvonalúságában/túlzott keretjellegében rejlik, ugyanis számtalan esetben nem határozza meg a jogalkotó, még az alapvető fogalmak tekintetében sem azt, hogy pontosan mely szervezeteket/személyeket kívánja az egyes fogalmak alá besorolni. Ennek ékes példája a közüzemi szolgáltatók fogalom-meghatározása, mely tekintetében az Eüsztv. felsorolta azon TEÁOR'08 szerinti

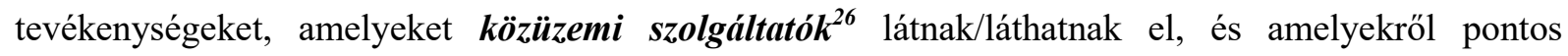
nyilvántartással rendelkezik például az állami adó- és vámhatóság, vagy a cégbíróság is, de a fogalmat egy olyan feltétellel bővítette ki, amellyel a jogszabály megalkotásakor, és hatálybalépése során egyetlen hivatal sem rendelkezett pontos nyilvántartással.

Ezen feltétel szerint kizárólag azon jogi személyek és/vagy egyéb szervezetek minősülnek közüzemi szolgáltatónak, amelyek a jogszabály által meghatározott tevékenysége(ke)n túl ,(..) a szolgáltatásaiért a tárgyévet megelőzö évben havonta átlagosan legalább 150.000 számlát bocsátott $k i .{ }^{\prime 2728}$

Elektronikus ügyintézésre kötelezettek esetében a jogszabály tételesen felsorolja azon személyeket, akik kötelesek elektronikusan eljárni az elektronikus ügytézést biztosító szervek előtt úgy, mint pl.:

- $\quad$ ügyfél:

○ gazdálkodó szervezet,

○ állam,

○ önkormányzat,

○ költségvetési szerv,

○ köztestület... stb.

- jogi képviselö ${ }^{29}$ :

○ egyéni ügyvéd,

○ ügyvédi iroda,

- jogtanácsos.

\footnotetext{
${ }^{26}$ Eüsztv. 1. § 33. pontja

${ }^{27}$ Eüsztv. 1. $\S 33$. pontja

${ }^{28}$ Közüzemi szolgáltatókat érintő probléma és annak esetleges megoldása a gyakorlatból:

Jelenleg a Belügyminisztérium nyilvántartása szerint legalább 17 darab olyan közüzemi szolgáltatót ismerünk, amelyek a jogszabályi feltételeknek megfelelnek. Fontos kiemelni, hogy a közüzemi szolgáltatók csoportját bizonyosan árnyalni fogja az Online Számlát érintő jogszabály-módosítások hatálybalépését követően, a statisztikai adatok felhasználása 2022 évtől, amikor is az állami adó- és vámhatóság pontos adatokkal fog vélhetően rendelkezni arról, hogy egy éven keresztül az Eüsztv. 1. § 33. pontja szerinti tevékenységen alapuló szolgáltatást nyújtó szolgáltatók lakossági/végfelhasználónak havonta, átlagosan legalább 150 ezer számlát bocsátottak-e ki.

${ }^{29}$ Eüsztv. 1. § 29. pontja
} 
Az elektronikus adó- és vámigazgatás szempontjából jelentős eljárási szereplőknek tekintendők az elektronikus kapcsolattartásra kötelezettek, melyekről az adóigazgatási rendtartásról szóló 2017. évi CLI. törvény (a továbbiakban: Air.) 36. §-a rendez. A törvény szerint elektronikus kapcsolattartásra köteles:

- aki az Eüsztv. alapján elektronikus ügyintézésre köteles,

- aki havi adó- és járulékbevallás benyújtására köteles ('08, vagy havi '58 jelü bevallás),

- aki az Áfa tv. szerint

○ összesítő nyilatkozat, vagy

○ összesítő jelentés benyújtására köteles

- az adóhatóság elektronikusan tart kapcsolatot az adózó meghatalmazottjával, ha az elektronikus kapcsolattartásra köteles és az egyéni vállalkozóval, valamint az Eüszt. szerinti jogi képviselővel, akkor is, ha az nem jogi képviselőként, vagy nem egyéni vállalkozói tevékenységével összefüggésben jár el.

\section{Az elektronikus ügyintézés szempontjából releváns „technikai” fogalmak:}

Azonositásra visszavezetett dokumentumhitelesités, azaz AVDH, „amely olyan szolgáltatás, amelynek keretében a jogszabályban meghatározott szolgáltató az ügyfél által rendelkezésre bocsátott nyilatkozatot az általa igazolt személyhez rendeli, majd a személyhez rendelést hitelesen igazolja." ${ }^{30}$

\section{Az AVDH gyakorlati alkalmazhatósága és jelentősége:}

Ezen szolgáltatás igénybevételével lényegében a KÜNY azonosítás segítéségével meghatározott fájltípusú például: „pdf” kiterjesztésű dokumentumokat láthatunk el AVDH-val és az e-Papír szolgáltatás igénybevételével időbélyegzővel, amelynek segítségével az e-Papír szolgáltatás alkalmazó hatóságok teljes bizonyító erejü magánokiratként ${ }^{31}$ ismerik el elektronikus eljárásaik során.

$\boldsymbol{K} \boldsymbol{A} \ddot{\boldsymbol{U}}$ azonosítási módok ${ }^{32}$ az elektronikus azonosítási szolgáltatásnak történő megfelelés érdekében:

- ügyfélkapus azonosítás (felhasználónév és jelszó párossal),

- e-Személyi Igazolvány használata (kártya tároló elem és PIN kód használata),

\footnotetext{
${ }^{30}$ Eüsztv. 1. $\S 5$. pontja

${ }^{31}$ A polgári perrendtartásról szóló 2016. évi CXXX. törvény (a továbbiakban: Pp.) 325. § (1) bekezdése szerint:

„(1) Teljes bizonyitó erejü a magánokirat, ha (...)

f) az elektronikus okiraton az aláíró a minösitett vagy minösitett tanúsítványon alapuló fokozott biztonságú elektronikus aláirását vagy bélyegzöjét helyezte el, és - amennyiben jogszabály úgy rendelkezik-azon időbélyegzöt helyez el,

g) az elektronikus okiratot az aláiró a Kormány rendeletében meghatározott azonosításra visszavezetett dokumentumhitelesítés szolgáltatással hitelesíti, vagy

h) olyan, törvényben vagy kormányrendeletben meghatározott szolgáltatás keretében jött létre, ahol a szolgáltató az okiratot a kiállitó azonositásán keresztül a kiállitó személyéhez rendeli és a személyhez rendelést a kiállitó saját kezü aláirására egyértelmüen visszavezethetö adattal együtt vagy az alapján hitelesen igazolja; továbbá a szolgáltató az egyértelmü személyhez rendelésröl kiállitott igazolást elektronikus dokumentumba kapcsolt, elválaszthatatlan záradékba foglalja és azt az okirattal együtt legalább fokozott biztonságú elektronikus bélyegzövel és legalább fokozott biztonságú időbélyegzővel látja el."

${ }^{32}$ E-ügyintézési rendelet 71. §-a
} 
- részleges kódú telefonos azonosítás (felhasználói azonosító és jelszó párossal).

Biztonságos kézbesítési szolgáltatás ${ }^{33}$ „olyan kézbesitési szolgáltatás, amely az elektronikus küldemény kézbesitésével kapcsolatosan az alábbi feltételek mindegyikének teljesülését biztositja:

- Ha a küldőtöl átvett üzenetet változatlan formában a címzett rendelkezésére bocsátották, akkor erröl a küldö számára legalább fokozott biztonságú elektronikus aláírással ellátott elektronikus dokumentumba foglalt igazolás álljon rendelkezésre." Azaz az elektronikus szolgáltatás a küldő számára elektronikus dokumentum formájában igazolja vissza a küldés tényét, amely dokumentumot a szolgáltatás elektronikus aláírással lát el.

- „Az üzenet és a kézbesitést igazoló okirat észrevétlenül nem megváltoztatható sem a kézbesités során, sem a kézbesitést követően." Jelen feltétel lényege, hogy az e-dokumentum mind az elküldést követôen, mind a dokumentum átvételét követően változatlan maradjon.

- „Az üzenet átvevője csak a címzett vagy a feljogositott helyettes átvevő lehet, és a tényleges átvevö személyét az átvétellel kapcsolatos okirat igazolja." Az üzenetet kizárólag az arra jogosult személy, vagy annak meghatalmazottja tudja átvenni, a szolgáltatás pedig visszaigazolja az átvétel tényét.

- „A feladónak okirati bizonyiték áll rendelkezésére (tértivevény) arról az esetről is, ha a kézbesités a megadott időn belül sikertelen; az igazolás a meghiúsulás időpontját és - ha azonositható - okát tartalmazza" ${ }^{34}$ A szolgáltatás legyen képes a kézbesítési fikció esetének kezelésére.

Biztonságos kézbesítési szolgáltatásra megfelelő példaként szolgál az állam által biztosított KÜNYregisztrációhoz kapcsolódó tárhely (KÜNY tárhely), Cégkapu, valamint Hivatali Tárhely is.

Az E-ügyintézési rendelet vezeti be az Eüsztv.-vel összefüggésben a Szabályozott Elektronikus Ügyintézési Szolgáltatás fogalmát (a továbbiakban: SZEÜSZ). A SZEÜSZ-k az elektronikus közigazgatási szolgáltatások „olyan új általános formája, amelyek segitségével az eddig papír alapú ügyintézési folyamatok gyorsabban, költséghatékonyabban és ügyfélorientáltan lehet elektronizálni, ezáltal segitséget, egységes hozzáférést és színvonalú szolgáltatásokat nyújtva az eljárásokat lefolytató közigazgatás szervek és az e-közigazgatási ügyintézéseket igénybe vevő ügyfelek (természetes és nem természetes személyek) számára. (...) A 379/2016. (XII. 2.) Korm. rendelet) 2017.01.01-jétöl az alábbi SZEÜSZ-ök szolgáltatását a NISZ Nemzeti Infokommunikációs Szolgáltató Zrt. (NISZ Zrt.) látja el:

- az ügyfél ügyintézési rendelkezésének nyilvántartása (RNY),

- iratérvényességi nyilvántartás (IÉNY),

- az ügyfél időszaki értesitése az elektronikus ügyintézési cselekményekröl (RÉR),

\footnotetext{
${ }^{33}$ Eüsztv. 1. § 11. pontja
}

${ }^{34}$ Eüsztv. 1. § 11. pontja 
- elektronikus fizetési és elszámolási rendszer (EFER),

- az ügyfelek részére nyújtott teljes körü azonositás szolgáltatás (RKTA, mint azonositási szolgáltatás)." 35

Szintén az E-ügyintézési rendelet fogalmazza meg a Központi Elektronikus Ügyintézési Szolgáltatás fogalmát (a továbbiakban: KË̈USZ), mely - a SZEÜSZ fogalma nyomán - szintén az elektronikus ügyintézés szempontjából jelöli azon szolgáltatásokat, amelyek hozzájárulnak ahhoz, hogy költséghatékony és szakmai, valamint technikai szempontból magas színvonalú szolgáltatásokat garantáljanak az együttműködő szervek az elektronikus ügyintézést igénybevevö/kötelezett ügyfelek számára. A KEÜSZ-t igénybevevő szolgáltatók (hatóságok, együttmüködő szervek) köre a jogalkotó által behatárolt. Jelenlegi jogszabályi környezetben KEÜSZ-ként tartjuk számon az alábbi szolgáltatásokat például:

- központi azonosítási ügynök, azaz a KAÜ,

- ÁNYK ürlapbenyújtás támogatási szolgáltatás, azaz az ÁBT,

- ügyfélkapu,

- elektronikus tájékoztatási szolgáltatás,

- összerendelési nyilvántartás, azaz az ÖNY,

- központi érkeztetési rendszer, azaz a KÉR... stb. ${ }^{36}$

5. A magyar kormányzat által biztosított elektronikus tárhelyek és ezzel kapcsolatos jogi alapfogalmak

Az elektronikus ügyintézés harmadik releváns pillérének kell tekintenünk. az elektronikus ügyintézés alapelvei és az elektronikus eljárás szereplőin túl, az elektronikus kapcsolattartást és ezzel kapcsolatos elektronikus tárhelyeket.

Elektronikus kapcsolattartásnak tekintjük, ha az ügyfél, vagy a hatóság az eljárást kezdeményező kérelmét, vagy aktusát, vagy azzal kapcsolatos nyilatkozatát, vagy döntését elektronikus úton teszi meg a másik fél irányába. ${ }^{37}$

\section{Elektronikus kapcsolattartásra szolgáló elérhetőség ${ }^{38}$ (a továbbiakban: hivatalos elérhetőség):}

\footnotetext{
${ }^{35}$ Szabályozott Elektronikus Ügyintézési Szolgáltatás. https://nyilvantarto.hu/hu/szabalyozott_elektronikus ui, 2019.12.30.

${ }^{36}$ Már müködö és még fejlesztés alatt álló KEÜSZ-ök. https://euf.gov.hu/elektronikus\#KE\%C3\%9CSZ-\%C3\%B6k, 2019.12.30.

${ }^{37}$ Eüsztv. 13. § (1) bekezdése

${ }^{38}$ Eüsztv. 14. §-a alapján: ,,(1) Gazdálkodó szervezet ügyfél - törvény eltérő rendelkezése hiányában a nyilvántartásba vételét, ha a gazdálkodó szervezet müködéséhez jogszabály által rendszeresitett nyilvántartásba vétele nem kötelezö, létrejöttét követö 8 napon belül - köteles bejelenteni az ügyintézési rendelkezésének nyilvántartásába (a továbbiakban: rendelkezési nyilvántartás) az elektronikus kapcsolattartásra szolgáló elérhetöségét (a továbbiakban: hivatalos elérhetőség), amely lehet

a) biztonságos kézbesitési szolgáltatási cím, vagy

b) a Kormány által rendeletben meghatározott egyéb típusú elektronikus elérhetöség.

(2) A gazdálkodó szervezet az elektronikus kapcsolattartásra szolgáló hivatalos elérhetöségének megváltozását a változás bekövetkezését megelözöen, a változás időpontjának megjelölésével bejelenti a rendelkezési nyilvántartásba.

(4) A hivatalos elérhetöségre kézbesitett küldemény kézbesitettnek minösül,
} 
- a biztonságos kézbesítési szolgáltatási cím, vagy

- a Kormány által jogszabály alapján biztosított egyéb típusú elektronikus elérhetőség:

○ KÜNY tárhely,

- Cégkapu,

○ Hivatali tárhely. ${ }^{39}$

A hivatalos elérhetőséggel szemben felállított jogszabályi követelmények (fogalmi elemek) jelentős hasonlóságot mutat a biztonságos kézbesítési szolgáltatás jogszabályi fogalom meghatározásával. A hivatalos elérhetőséget az elektronikus ügyintézésre kötelezett gazdálkodó szervezeteknek be kell jelenteniük az ügyintézési rendelkezések nyilvántartásába (a továbbiakban: $\boldsymbol{R} N \boldsymbol{Y}$ ).

KÜNY tárhely használatra kötelezettek az egyéni vállalkozók, figyelemmel az E-ügyintézési rendelet 88/A. §-ára. A természetes személy ügyfelek ezzel szemben jogosultak a KÜNY tárhely használatára.

Cégkapu használatra kötelezettek, egyéb biztonságos kézbesítési szolgáltatási cím, vagy Hivatali tárhely hiányában, az E-ügyintézési rendelet 89-91. §-ai szerint a gazdálkodó szervezetek, az egyéni ügyvéd, az európai közösségi jogász, valamint az egyéni szabadalmi ügyvivő.

Cégkapu vélelem a cégkapu elektronikus tárhely vonatkozásában meghatározott jogszabályi fikció. Ennek lényege, hogy a cégkapura belépő személyről vélelmezi a hatóság, hogy a cégkapura küldött, vagy onnan továbbított küldemények szempontjából jogosult eljárni. Ám a cégkapu hozzáférés (bejelentkezés) esetén a belépés során ez a szolgáltatás a hatóságok szempontjából nem végzi el a belépő személy viszontazonosítását, ezért a cégkapu hozzáférés nem teremt kifejezett eljárási jogosultságot

a) ha a hivatalos elérhetöséget biztositó szolgáltató a küldemény ügyfél által történö átvételét igazolja vissza, az igazolásban feltüntetett idöpontban,

b) ha a hivatalos elérhetöséget biztositó szolgáltató azt igazolja vissza, hogy a küldemény átvételét a címzett megtagadta, a megtagadásra vonatkozó igazolásban feltüntetett idöpontban, vagy

c) ha a hivatalos elérhetöséget biztositó szolgáltató azt igazolja vissza, hogy a küldeményt a címzett kétszeri értesítése ellenére nem vette át, a második értesités igazolásban feltüntetett időpontját követö ötödik munkanapon.

(6) Hivatalos elérhetöségként olyan elérhetöség adható meg, amely

a) egyértelmüen azonosithatóan kizárólag az adott gazdálkodó szervezet elérhetösége,

b) alkalmas a küldés és fogadás idöpontjának, valamint az átvevö személynek egyértelmü elektronikus azonositására,

c) garantálja a dokumentum sértetlen fogadását,

d) kezeli a sikertelen kézbesités eseteit,

e) a (4) bekezdésben foglaltak visszaigazolására alkalmas.

(7) A Kormány rendeletében jelöli ki azon szolgáltatót, akivel az e tárgyban kötött külön közszolgáltatási szerzödésben foglaltak alapján az (1) bekezdés a) pontja szerinti elérhetöséget a Kormány rendeletében meghatározott szervek részére ingyenesen biztositja.

(8) Ha a gazdálkodó szervezet ügyfél hivatalos elérhetöséggel nem rendelkezik, az elektronikus ügyintézést biztositó szerv az eljárást elektronikus kapcsolattartás nélkül is lefolytathatja azzal, hogy a gazdálkodó szervezet ezen kötelezettségének nem teljesitése miatt az elektronikus ügyintézést biztositó szerv kezdeményezi a gazdálkodó szervezettel szembeni, törvényben meghatározott törvényességi felügyeleti eljárás vagy hatósági ellenörzés lefolytatását.

(9) $25 \mathrm{Ha}$ a gazdálkodó szervezet közhiteles nyilvántartásban szerepel, a gazdálkodó szervezet nyilvántartását vezetö szerv a hivatalos elérhetöség nyilvántartásba vétele, valamint üzemeltetése érdekében elektronikus úton, térítésmentesen átadja a rendelkezési nyilvántartást vezetö szervnek, valamint a gazdálkodó szervezet által megjelölt biztonságos kézbesitési szolgáltatási cím szolgáltatónak a gazdálkodó szervezetre vonatkozó, a gazdálkodó szervezet és a képviseletére jogosult személy azonositásához szükséges, az adott nyilvántartásban szereplö nyilvános adatokat. Az adatszolgáltatás lebonyolításának technikai szabályait az érintett szervek megállapodásban rögzítik.

(10) Az egyéni vállalkozó hivatalos elérhetöségét a Kormány rendeletében meghatározott módon jelenti be."

${ }^{39} \mathrm{~A}$ Belügyminisztérium Elektronikus Ügyintézési Felügyeleti Főosztály tájékoztatása: Költségvetési szervek, önkormányzatok cégkapus, hivatali kapu regisztrációja. https://adozasitanacsadas.hu/hir/836/koltsegvetesi-szervek-onkormanyzatok-cegkapus-hivatali-kapuregisztracioja, 2020.01.01. 
elektronikus és papíros ügyintézés során a hatóság előtt. Továbbá az ügyfél képviseletében elektronikus szolgáltatások igénybevételére sem jogosítja fel a cégkapuhoz hozzáféréssel rendelkező személyt. A cégkapura belépő személy úgy kell „elképzelnünk”, mint például a klasszikus postai kézbesítés során a cég székhelyén a titkárnőt jogosult személynek tekintjük a postai küldemények átvételére, vagy azok feladására a cég „képviseletében”, de ez a feltételezett eljárási jogosultság nem teremt arra lehetőséget a titkárnőnek, hogy a cég hivatalos ügyeiben eljárjon, nyilatkozzon. Ezért jellemezhetjük úgy a cégkaput, hogy az nem tekintendő viszontazonosító szolgáltatásnak úgy, mint a KÜNY tárhely.

Hivatali Tárhely használatra kötelezettek az E-ügyintézési rendelet 84-87. §-ai szerint az együttmüködő szervek számára nyújtott hivatalos elektronikus kapcsolattartásra szolgáló tárhely.

\section{Összegzés}

Összegezve tanulmányomban leírtakat kijelenthetjük, hogy az elektronikus ügyintézés a Ket.-ben deklarált kezdeti szabályozásához és kapcsolattartási „lehetőséghez” képest az elmúlt évtizedben jelentős változáson esett át. A jogalkotó számtalan, jogi és technikai szempontból releváns, elektronikus ügyintézéssel kapcsolatos területet kívánt leszabályozni az elmúlt évek során, de emellett számos nyitott kérdés maradt még az e-közigazgatás vonatkozásában, amely későbbi tanulmányaim tárgya lesz ( $l s d$. IIIII. fejezet).

Ha napjainkban elektronikus ügyintézésről beszélünk, akkor elsősorban nem kapcsolattartási módról, hanem már számtalan és az ügyfelek szempontjából hasznos - a háttérben SZEÜSZ és KEÜSZ által garantált - szolgáltatás együttesére gondolunk. Ezen perspektíva váltáshoz nélkülözhetetlen volt, hogy a jogalkotó interpretálja a EU-s szabályozás e-ügyintézést garantáló rendelkezéseit (eIDAS rendelet) és megteremtse az elektronikus ügyintézés alapját garantáló, törvényi szintű rendelkezéseket, azaz az Eüsztv.-t.

Az Eüsztv. kódexszerúen kívánja szabályozni az elektronikus ügyintézést, amelyet a közigazgatási hatóságok, hatósági feladatokat ellátó együttmüködő szervek szempontjából úgy ítélhetünk meg, hogy az Eüsztv. egyrészt a klasszikus közigazgatási eljárások és szolgáltatások tényleges alternatíváját kívánja biztosítani a hatóságok és ügyfelek részére. Ezért meghatározza az elektronikus közigazgatási eljárás alapját garantáló:

1. alapelveket,

2. az e-ügyintézés alanyait (mind a hatóság, mind az ügyfelek szempontjából),

3. az elektronikus ügyintézés technikai hátterét, valamint

4. az elektronikus eljárások valamennyi fontosabb alapfogalmát úgy, mint pl.: az elektronikus tárhelyeket és e-kapcsolattartási kötelezettséget. 
A jövő igazi kérdése a közigazgatási eljárásjog szempontjából az, hogy jelen jogszabályi környezet figyelemmel az OECD és az EU által támasztott, elektronikus közigazgatással kapcsolatos elvárásokra - az elkövetkezö évtizedben olyan irányba fog-e fejlödni, amely az elektronikus ügyintézést nem csak egy alternatívaként, hanem - a magyar társadalom digitális analfabetizmusát leredukálva és az elektronikusan intézhetö ügyek körét kiterjesztve - azt elsődleges eljárási és ügyintézési módként szabályozza.

\section{Irodalomjegyzék}

Könyv, könyvfejezet:

1. Veszprémi B. (2019): A stratégiai-alkotástól az e-hitelesitésig vezetó út. Kitekintés a magyar eközigazgatás fontosabb témaköreire, Debreceni Egyetemi Kiadó, Debrecen, 2019., pp. 222-240.

2. Veszprémi B. - Czékmann Zs. (2013): Az e-közigazgatás szakigazgatási alapjai, In: Lapsánszky A. (2013): Közigazgatási jog. Fejezetek szakigazgatásaink köréből. I. kötet, Complex Kiadó, Budapest, 2013.

Folyóirat cikk:

3. Tózsa I. (2012): Az elektronikus közigazgatás helyzete, Új Magyar Közigazgatás, 2012/5., pp. $2-12$.

4. Veszprémi B. (2019): Az interoperabilitás kérdésének boncolgatása a közigazgatásban, Pro Publico Bono, Magyar Közigazgatás, 2018/2., pp. 174-184.

Internetes cikkek, oldalak:

5. Architecture for a European interoperable eID system within a smart card infrastructure, CEN Workshop Agreement, CWA 15264-1, 2005. https://joinup.ec.europa.eu/solution/architectureeuropean-interoperable-eid-system-within-smart-card-infrastructure, 2020.01.01.

6. A Belügyminisztérium Elektronikus Ügyintézési Felügyeleti Főosztály tájékoztatása: Költségvetési szervek, önkormányzatok cégkapus, hivatali kapu regisztrációja. https://adozasitanacsadas.hu/hir/836/koltsegvetesi-szervek-onkormanyzatok-cegkapushivatali-kapu-regisztracioja, 2020.01.01.

7. Elektronikus Személyazonositó Kártya, Képviselői Információs Szolgálat, InfoJegyzet, 26/2015. http://www.parlament.hu/documents/10181/303867/2015_26_e-kartya/3e64ca477986-47d4-a43b-48822fe0b8c8, 2019.12.31.

8. Központi Azonositási Ügynök. https://ugyintezes.magyarorszag.hu/szolgaltatasok/kau.html, 2019.12.30.

9. Már müködö és még fejlesztés alatt álló KEÜSZ-ök, https://euf.gov.hu/elektronikus\#KE\%C3\%9CSZ-0C3\%B6k, 2019.12.30. 
10. Szabályozott Elektronikus Ügyintézési Szolgáltatás, https://nyilvantarto.hu/hu/szabalyozott_elektronikus_ui, 2019.12.30.

Törvények, rendeletek:

11.910/2014/EU rendelet - a belső piacon történő elektronikus tranzakciókhoz kapcsolódó elektronikus azonosításról és bizalmi szolgáltatásokról, valamint az 1999/93/EK irányelv hatályon kívül helyezéséről (eIDAS rendelet)

12. 2016. évi CXXX. törvény - a polgári perrendtartásról (Pp.)

13. 2015. évi CCXXII. törvény - az elektronikus ügyintézés és a bizalmi szolgáltatások általános szabályairól (Eüsztv.)

14. 2004. évi CXL. törvény - a közigazgatási hatósági eljárás és szolgáltatás általános szabályairól (Ket.)

15. 451/2016. Korm. rendelet - az elektronikus ügyintézés részletszabályairól (E-ügyintézési rendelet)

16. 83/2012. Korm. rendelet - a szabályozott elektronikus ügyintézési szolgáltatásokról és az állam által kötelezően nyújtandó szolgáltatásokról 